\title{
REENCUENTRO
}

\section{Escuela y cultura de confluencia}

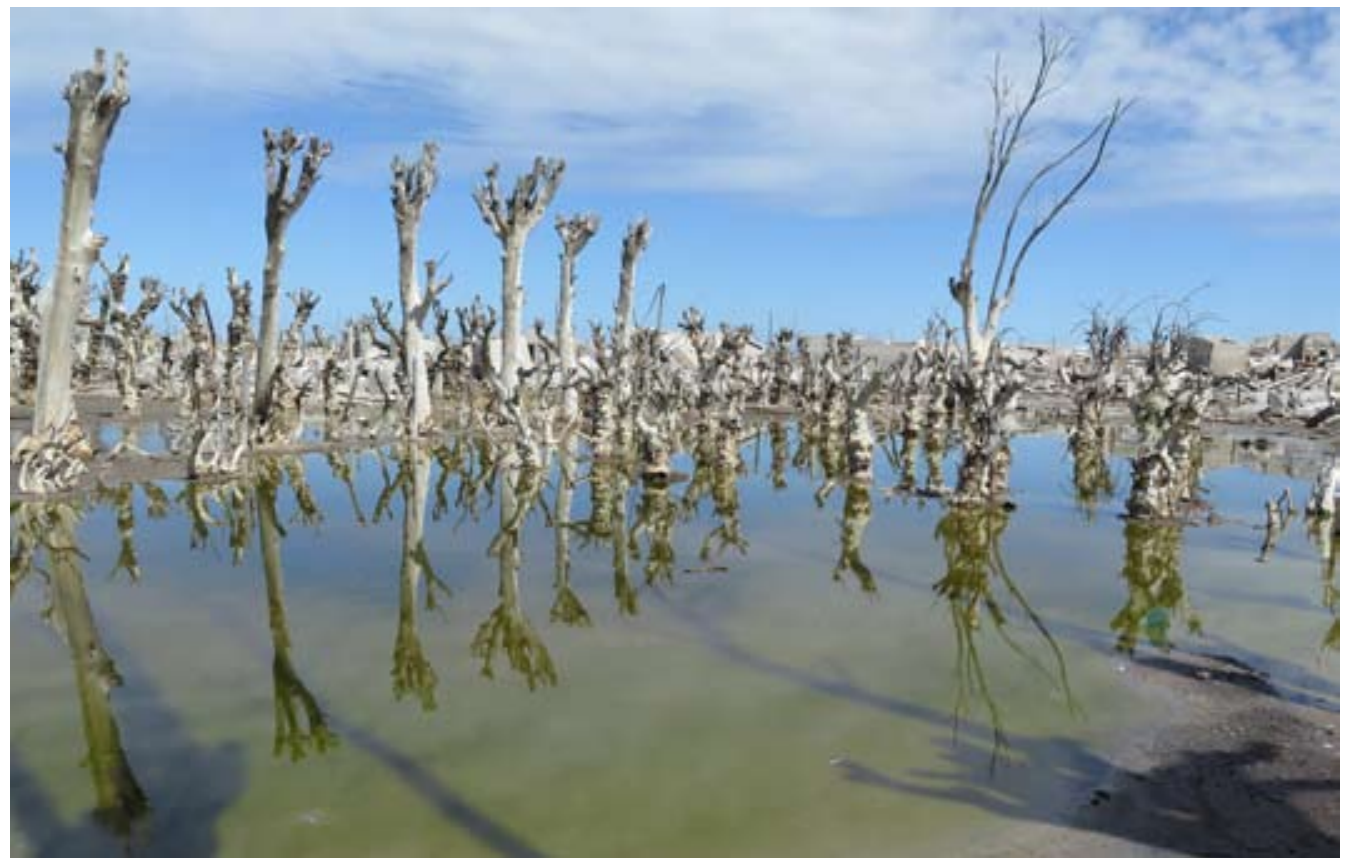

S/T (colección Volver), fotografía. Patricia Bonjour

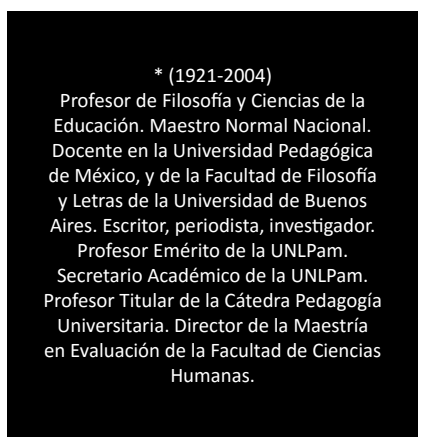

Caldén No 11, octubre de 1987| Revista de la Dirección General de Cultura del Ministerio de Educación y Cultura, Gobierno de la provincia de La Pampa

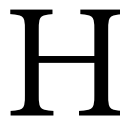
abida cuenta del entrañable, inseparable nexo entre cultura y educación, se nos suscitan interrogantes acerca del papel de la escuela pública en la integración de la cultura del saber y la cultura del ser para consolidar una genuina cultura válida. Apelamos al que podemos llamar provisionalmente modelo pampeano para la búsqueda de respuestas que nos permitan ahondar en el problema y, de paso, recortar el perfil de nuestra identidad cultural.

El territorio de La Pampa nació, institucionalmente, el mismo año que la Ley 1420 de Educación Común, en 1884. El Congreso Pedagógico de 1882, y el histórico debate legislativo que constitu- 
yen el marco de referencia para la promulgación de la hoy arrumbada ley -nunca totalmente cumplida- se constituyeron en sustrato ideológico incuestionable del modelo pampeano..

Bien sabe (o acaso apenas lo sepan las generaciones de maestros formados en pleno deterioro del normalismo argentino) bien se sabe que el magisterio puntano, entrerriano y pampeano en nuestro territorio, se formó en los términos pedagógicos y filosóficos requeridos por un "proyecto nacional" centrado en una economía agroexportadora y, en la Pampa Central, eventualmente de cuño agrario pastoril.

"la escuela del desierto", como la llamó Eduardo Thames Alderete en su libro, al igual que los Informes de fines y principios de siglo elaborados por los visitadores e inspectores, presidentes e inspectores, presidentes y vocales del Consejo Nacional de Educación, reflejan claramente la inquietud sarmientina de transformar el país -todo el país- en una inmensa escuela forjadora del hombre nuevo de una Argentina gestada en el ideario de la Revolución de Mayo y proyectada en la Generación del 37 a través del Dogma Socialista de Esteban Echeverría, las Bases y puntos de partida para la organización política de la República Argentina que el luminoso Alberdi planteó como avanzada de la democracia, el repertorio antiautoritario de Juan María Gutiérrez y, claro está, Educación Popular, texto fundamental y fundador de la pedagogía argentina en el que Sarmiento asienta la premisa de su laborioso quehacer, "educar al soberano" a la par del lema alberdiano "gobernar es poblar".

Viajeros ilustres, sabios cabales, escritores-periodistas, políticos destacados, dramaturgos, cubrieron el espacio bibliográfico, los cuadros de viajes, las memorias, las crónicas, vaticinando el venturoso futuro de la que sería -allí nomás, al filo de la llamada "conquista del desierto" - una nueva provincia. Para garantizar las exitosas jornadas venideras allí estaban, juntos, el arado y la escuela. Nacían los pueblos, y con ellos, una cultura distinta de acuerdo con la forma de ser de los pobladores en su "habitar" precario de colonos.

Las denuncias de quienes no cayeron en la trampa de los terratenientes y se ampararon en la Liga Agraria en la década de 1910 a 1920, llámense georgistas o socialistas, sean tildados de anarquistas o maximalistas, revelan la frustración y el desengaño de aquella "quinera del trigo". Los que pagaron con cárcel, pobreza y desgracia la patriada de enfrentar a las empresas latifundistas, contaron -bueno es señalarlo-, con la solidaridad de un solo gremio: el de los maestros.

La escuela pampeana -la rural y la urbana- se sostuvo en la dignidad de los principios rectores que le dieron origen. Siempre hubo un maestro allá donde los trabajadores del campo y las aldeas de la vasta ruralia pampeana necesitaron apoyo. Se cuentan por decenas los docentes que fundaron periódicos revistas, bibliotecas populares e instituciones culturales. Si en algún momento de nuestra batalla contra el analfabetismo supimos y pudimos estar en la vanguardia de los estados con menores tasas, fue porque pueblo y escuela fueron uno sólo en la lucha contra la ignorancia.

Esa unidad entre pueblo y escuela posibilitó la apertura hacia el encuentro de un ideal antropológico que restañase las heridas y las llagas abiertas por las guerras de exterminio contra el indio. Ya es un lugar común hablar de la Argentina como un "crisol de razas". Pero no lo es tanto si, por encima de la remanida metáfora, se piensa que aquí, en La Pampa, las escuelas del pueblo -las de la ley 1420- fueron eso.

Nuestra escuela no aculturó, integró. Allí nos mezclamos todos, los hijos de inmigrantes españoles, italianos, alemanes, franceses: los criollos hijos de los milicos en "la conquista" que, al igual que el indio, pagaron su tributo de sangre para fertilizar las tierras del latifundista; y claro está, los diezmados herederos de las dos grandes dinastías aborígenes.

Maestros como Daniel Gatica, los Guaycochea, Enrique Stieben, Téllez de Meneses, Miguel de Fougeres -y cito solamente algunosaprendieron la dulce lengua mapuche para que se estableciera una relación empática bilingüe que fuera a la vez bicultural. Las toponimias de Gatica, Guaycochea y Stieben constituyen, junto con trabajos del excepcional docente que fue Ramón Elizondo, testimonios bibliográficos que reflejan en qué medida el magisterio pampeano hizo suyo el mandato de la ley. La integración étnica abarcó igualmente a los extranjeros e hijos de extranjeros que se expresaban en las formas dialectales europeas. El idioma nacional fue el factor de cohesión sociocultural. No se adoptaron por cierto criterios didácticos orientados hacia la regionalización de los contenidos. La meta, por entonces, 
fue la de enfatizar lo nacional, máxime en estas tierras de "pan llevar", tierras de aluvión inmigratorio todavía sin identidad regional.

No creemos que fuera negativa esa enfatización de lo nacional. En lo familiar, en lo político, en lo económico, en la interrelación social, la educación nacional -sin prejuicios chauvinistas- fue, aún con sus exageraciones patrioteras, el principal factor de unidad cultural.

Aquella tríada Región-Nación-Universo, que servía de apoyo a la unidad ecuménica de una cultura sin adjetivos y que José Ingenieros planteó inductivamente en su "Sociología argentina” sostuvo, aquí en La Pampa, un planteamiento deductivo, es decir, marchó de lo general a lo particular. La escuela y sus maestros "hicieron patria" subsumiendo lo regional en lo nacional.

La tesis que sostuviéramos en el Simposio Nacional de Folklore (Cosquín 1968) estaba referida a lo que, en acuerdo con las proposiciones de Antonio Gramsci, constituye un folklore de confluencia, de base sencillamente dialéctica.

Los maestros de La Pampa refrendaron en los hechos las consignas de un saludable nacionalismo, a la vez que participaron activamente en las asambleas destinadas a reivindicar los fueros del campesinado. Fue por eso, y por su empeño en crear condiciones favorables para el desarrollo del cooperativismo, que en las postrimerías del gobierno de facto del uriburismo, se hiciera constar en la Memoria de esos aciagos años que "las escuelas de La Pampa constituían una verdadera vergüenza nacional, algo así como una sucursal bolchevique de la cual la Asociación de Maestros Pampeanos constituía el "presidium soviético en La Pampa”.

Esa acusación que a la postre -viniendo de quien venía- resulta un elogio, tenía un asidero seguramente en el Manifiesto al Pueblo de La Pampa hecho público el 11/10/1928, en ocasión del Congreso de Maestros Pampeanos y del que participaron 364 delegados de todo el ex territorio. El fraternal llamado al laborioso pueblo pampeano inserto en el documento, para luchar hombro a hombro con los maestros "en la obra de mejoramiento social y cultural" de la población, encontró amplia resonancia en la prensa diaria y periódica de la República. Uno de los participantes, el maestro y abogado Edmundo Rosales dijo entonces que "La decisión del magisterio pampeano de hermanarse con los obreros y los campesinos en esa lucha ardua por una mayor justicia en la distribución de la riqueza social y por el derecho a la cultura, es una declaración que lo honra".

El fervor cultural del magisterio pampeano hizo que la escuela no quedase cercada en un didactismo aséptico. El hecho de que ninguna localidad careciera de una Biblioteca Popular, incorporó a la educación sistemática un soporte para sistemático que, tal como se señaló en el Primer Congreso de bibliotecas de La Pampa en 1957, "fue el indicado preciso de la variable cultural que sirvió de baremo para establecer los índices cualitativos del progreso y la evolución provincial". Ese hecho tuvo casi siempre, un maestro a la cabeza.

También los maestros encabezaron la lista protagónica del periodismo regional pampeano. Los maestros pampeanos, por último, fueron precursores de una cultura regional en las letras, y ayer como hoy, aportaron su talento y creatividad más allá de las aulas.

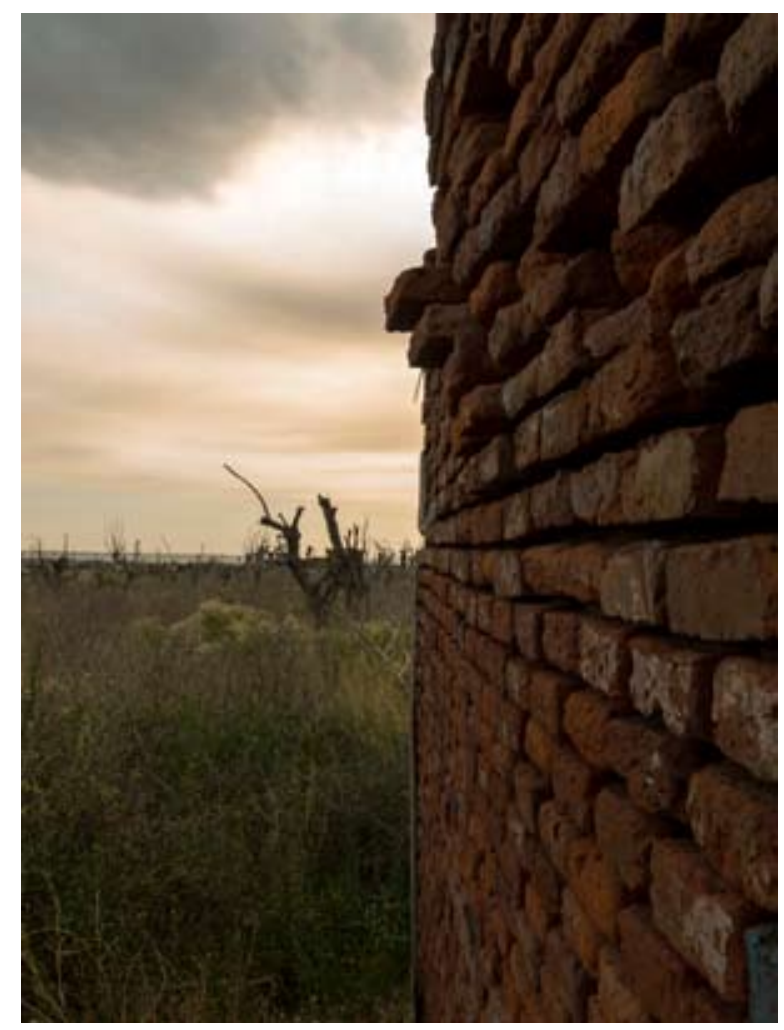

S/T (colección Volver), fotografía. Patricia Bonjour 